\title{
Influences of oceanic ozone deposition on tropospheric photochemistry
}

\author{
Ryan J. Pound ${ }^{1}$, Tomás Sherwen ${ }^{1,2}$, Detlev Helmig ${ }^{3}$, Lucy J. Carpenter ${ }^{1}$, and Mat J. Evans ${ }^{1,2}$ \\ ${ }^{1}$ Wolfson Atmospheric Chemistry Laboratories, Department of Chemistry, University of York, York, YO10 5DD, UK \\ ${ }^{2}$ National Centre for Atmospheric Science, University of York, York, YO10 5DD, UK \\ ${ }^{3}$ Institute of Alpine and Arctic Research, University of Colorado at Boulder, Boulder, CO 80303, USA
}

Correspondence: Ryan J. Pound (rp819@york.ac.uk)

Received: 11 November 2019 - Discussion started: 20 November 2019

Revised: 20 February 2020 - Accepted: 13 March 2020 - Published: 9 April 2020

\begin{abstract}
The deposition of ozone to seawater is an important ozone sink. Despite constituting as much as a third of the total ozone deposition, it receives significantly less attention than the deposition to terrestrial ecosystems. Models have typically calculated the deposition rate based on a resistance-in-series model with a uniform waterside resistance. This leads to models having an essentially uniform deposition velocity of approximately $0.05 \mathrm{~cm} \mathrm{~s}^{-1}$ to seawater, which is significantly higher than the limited observational dataset. Following from Luhar et al. (2018) we include a representation of the oceanic deposition of ozone in the GEOS-Chem model of atmospheric chemistry and transport based on its reaction with sea-surface iodide. The updated scheme halves the calculated annual area-weighted mean deposition velocity to water from $0.0464 \mathrm{~cm} \mathrm{~s}^{-1}$ (25th and 75th percentiles of $0.0461 \mathrm{~cm} \mathrm{~s}^{-1}$ and $0.0471 \mathrm{~cm} \mathrm{~s}^{-1}$ respectively) to $0.0231 \mathrm{~cm} \mathrm{~s}^{-1}$ (25th and 75th percentiles of $0.0121 \mathrm{~cm} \mathrm{~s}^{-1}$ and $0.0303 \mathrm{~cm} \mathrm{~s}^{-1}$ respectively). The calculated ozone deposition velocity varies from $0.009 \mathrm{~cm} \mathrm{~s}^{-1}$ in polar waters to $0.040 \mathrm{~cm} \mathrm{~s}^{-1}$ at the tropics. This improves comparisons to observations. The variability is driven mainly by the temperature-dependent rate constant for the reaction between iodide and ozone, the temperature dependence of the solubility, and variations in the ocean iodide concentration. The calculated annual deposition flux of ozone to the ocean is reduced from 222 to $122 \mathrm{Tgyr}^{-1}$, and overall deposition of ozone to all surface types reduces from 862 to $758 \mathrm{Tg} \mathrm{yr}^{-1}$. Tropospheric ozone burdens and global mean $\mathrm{OH}$ increase from 324 to $328 \mathrm{Tg}$, and from $1.17 \times 10^{6}$ to $1.18 \times 10^{6}$ molec. $\mathrm{cm}^{-3}$, respectively. A total of $34 \%$ of surface grid boxes experience a $10 \%$ or greater increase in
\end{abstract}

ozone concentration. Comparisons between observations of surface ozone and the model are improved with the new parameterization notably around the Southern Ocean. Processlevel representation of oceanic deposition of ozone thus appears essential for representing the concentration of surface ozone over the planet.

\section{Introduction}

Tropospheric ozone is an important secondary pollutant. Globally it causes one million premature deaths a year (Malley et al., 2017), degrades ecosystems (Fowler et al., 2008) and is a greenhouse gas (IPCC, 2013). Transport from the stratosphere and in situ chemical production are balanced by chemical destruction and dry deposition to the surface. Total dry deposition of ozone is thought to amount to $\sim 978 \mathrm{Tg} \mathrm{yr}^{-1}$ (Hardacre et al., 2015) compared to $\sim 500 \mathrm{Tg} \mathrm{yr}^{-1}$ transported from the stratosphere, $\sim 5000 \mathrm{Tg} \mathrm{yr}^{-1}$ for chemical production and $\sim 4500 \mathrm{Tg} \mathrm{yr}^{-1}$ for chemical loss (Young et al., 2018). Whilst dry deposition velocity to the ocean is thought to be slow $\left(\sim 0.05 \mathrm{~cm} \mathrm{~s}^{-1}\right)$ compared to vegetation $\left(\sim 0.1 \mathrm{~cm} \mathrm{~s}^{-1}\right)$, the larger area of the ocean compared to the land results in ozone deposition to the ocean representing approximately one-third of the total deposition (Ganzeveld et al., 2009).

The ultimate sink of ozone to the ocean is due to chemical reactions. The reaction of ozone with iodide $\left(\left[\mathrm{I}^{-}\right]\right)$in the surface layer of the ocean via the simplified Reaction (R1) (Garland and Curtis, 1981; Sakamoto et al., 2009; Hayase et al., 2010; Carpenter et al., 2013) is believed to be the 
dominant mechanism (Garland et al., 1980). The transport of ozone within the ocean surface also plays an important role in this process; a simplified version of the relevant processes is shown in Fig. 1.

$\mathrm{O}_{3}+\mathrm{I}^{-}+\mathrm{H}^{+} \rightarrow \mathrm{HOI}+\mathrm{O}_{2}$

In addition, dissolved organic carbon (DOC) has been shown to react with dissolved ozone and have an enhancing effect on ozone deposition similar to that of iodide (Martino et al., 2012; Shaw and Carpenter, 2013), but it is less well understood. Dimethyl sulfide (DMS) and bromide have also been shown to enhance ozone deposition velocity but by small amounts (Sarwar et al., 2016).

The net flux of a gas to a surface $F$ is calculated as the atmospheric concentration at the ocean surface $C$ multiplied by the deposition velocity, $v_{\mathrm{d}}$, shown in Eq. (1).

$F=-v_{\mathrm{d}} C$

The deposition velocity $\left(v_{\mathrm{d}}\right)$ in many models is calculated using the resistance-in-series scheme (Wesely and Hicks, 1977) shown in Eq. (2). This describes the different limiting factors of the deposition: transport to the surface through turbulent transport $\left(r_{a}\right)$; transport through the quasilaminar sub-layer, which is the air directly in contact with a surface $\left(r_{b}\right)$; and the physical, chemical or biological loss of the molecule at the surface (the ocean in this case) $\left(r_{\mathrm{c}}\right)$.

$v_{\mathrm{d}}=\frac{1}{r_{a}+r_{b}+r_{\mathrm{c}}}$

The relative importance of the different resistances is dependent primarily on the gas being considered. Gases that are highly soluble (such as sulfur dioxide) will have a small $r_{\mathrm{c}}$, so their limiting factors are the atmospheric resistances $\left(r_{a}\right.$ and $r_{b}$ ). Less soluble gases such as ozone are limited by the chemical loss at the surface $\left(r_{\mathrm{c}}\right)$. Wesely (1989) gives a value of $r_{\mathrm{c}}=2000 \mathrm{~s} \mathrm{~m}^{-1}$ for ozone in all water types, and this is used in most atmospheric chemistry models (Hardacre et al., 2015; Luhar et al., 2017, 2018). This chemical loss of ozone is the limiting factor for ozone deposition ( $95 \%$ of the sum of the resistances is the value of $r_{\mathrm{c}}$; Chang et al., 2004) and so yields an almost constant $\left(0.05 \mathrm{~cm} \mathrm{~s}^{-1}\right)$ overall deposition velocity, with only small variation due to meteorological variation in $r_{a}$ and $r_{b}$. However, observations of ozone deposition show significant variability. From the observations collated by Ganzeveld et al. (2009), fresh water deposition velocities range from 0.01 to $0.1 \mathrm{~cm} \mathrm{~s}^{-1}$, with ocean observations ranging from 0.01 to $0.15 \mathrm{~cm} \mathrm{~s}^{-1}$. The higher values of ocean observations are likely influenced by coastal effects such as those described by Bariteau et al. (2010), with the open-ocean observations being substantially lower (0.009$0.065 \mathrm{~cm} \mathrm{~s}^{-1}$ ) (Helmig et al., 2012).

Given this observed variability, the fixed $r_{\mathrm{c}}$ approach appears overly simple. Based on Fairall et al. (2007) and Luhar et al. (2017), Luhar et al. (2018) formulated a new scheme for calculating $r_{\mathrm{c}}$ which explicitly takes into account the simultaneous effects of chemical reactions in the ocean with iodide and the physical processes of molecular diffusion and turbulent transfer in the ocean surface. This considers three oceanic layers (Fig. 1): a very shallow "surface reaction-diffusion" layer that represents the region of the ocean through which the $\mathrm{O}_{3}$ can diffuse from the ocean before it reacts in the ocean, which lies above a thicker turbulent layer which is mixed by wind-stress-driven turbulence, which in turn lies above the "bulk" ocean. The loss of $\mathrm{O}_{3}$ is determined by the chemical reactivity within the reactiondiffusion layer, which is supplied by $\mathrm{I}^{-}$from below. The resulting scheme, derived by Luhar et al. (2018), is based on solving the fundamental equation for the conservation of mass of a reacting and diffusing substance in water (Fairall et al., 2007) and yields Eq. (3).

$r_{\mathrm{c}}=\frac{1}{\alpha \sqrt{a D}}\left[\frac{\Psi K_{1}\left(\xi_{\delta}\right) \sinh (\lambda)+K_{0}\left(\xi_{\delta}\right) \cosh (\lambda)}{\Psi K_{1}\left(\xi_{\delta}\right) \cosh (\lambda)+K_{0}\left(\xi_{\delta}\right) \sinh (\lambda)}\right]$

Here $\alpha$ is the dimensionless solubility, $a$ is the chemical reactivity of $\mathrm{O}_{3}$ with sea-surface iodide (the product of $\left[\mathrm{I}^{-}\right]$and the second order rate-coefficient, $k), D$ is the diffusivity of $\mathrm{O}_{3}$ in water, $\Psi$ is defined in Eq. (5) where $u_{\mathrm{w}}^{*}$ is the waterside friction velocity, $\delta_{\mathrm{m}}$ is the thickness of the reactiondiffusion layer of the sea-surface microlayer, $\kappa$ is the von Kármán constant $(\approx 0.4), \xi_{\delta}$ defined in Eq. $(4), \lambda$ is defined in Eq. (6), and $K_{0}$ and $K_{1}$ are modified Bessel functions of the second kind with order zero and one respectively.

$\xi_{\delta}=\left[\frac{4 a}{\kappa u_{\mathrm{w}}^{*}}\left(\delta_{\mathrm{m}}+\frac{D}{\kappa u_{\mathrm{w}}^{*}}\right)\right]^{\frac{1}{2}}$
$\Psi=\left[1+\left(\frac{\kappa u_{\mathrm{w}}^{*} \delta_{\mathrm{m}}}{D}\right)\right]^{\frac{1}{2}}$
$\lambda=\delta_{\mathrm{m}} \sqrt{\frac{a}{D}}$

In this paper we include this description of ozone deposition to the ocean in the GEOS-Chem model and explore the impact on the composition of the troposphere. In Sect. 2 we describe the GEOS-Chem model and the implementation of the new scheme. In Sect. 3 we describe the impact of the new scheme on the deposition velocities of ozone to the ocean in the model and assess them against observations of deposition velocities. The impacts of the new deposition scheme on the composition of the troposphere are described in Sect. 4 together with comparison to observations of surface ozone. Finally we draw some conclusions in Sect. 5.

\section{Modelling}

We use here version 12.1.1 of the 3-D global chemical transport model GEOS-Chem "Classic" (Bey et al., 


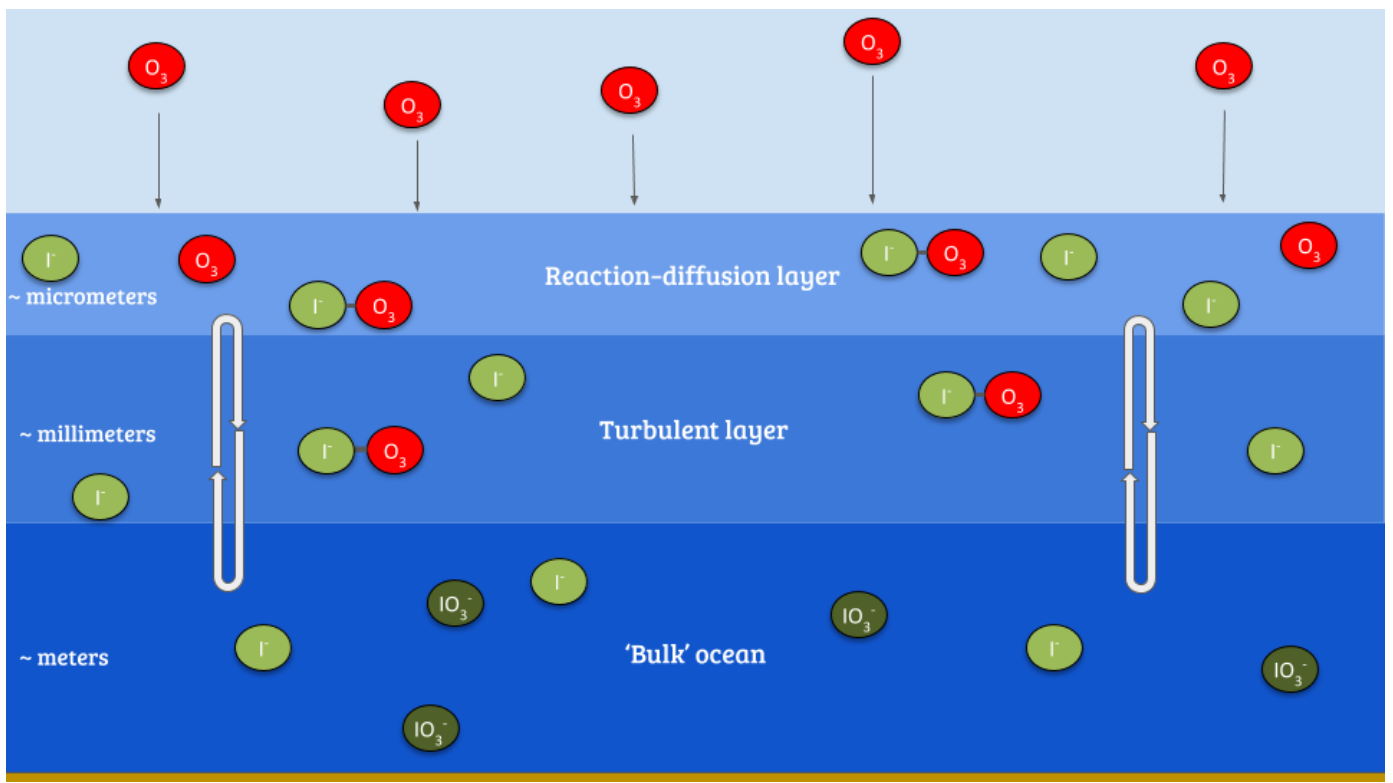

Figure 1. Illustration of the reaction of ozone with $\mathrm{I}^{-}$in the sea surface, also demonstrating a simplified version of the surface structure where the reaction occurs.

2001) (http://www.geos-chem.org, last access: 20 February 2020) driven by assimilated meteorology from the NASA Global Modeling and Assimilation Office. GEOS-Chem includes $\mathrm{HO}_{x}-\mathrm{NO}_{x}-\mathrm{VOC}$ ozone-halogen-aerosol tropospheric chemistry with the halogen (chlorine, bromine and iodine) chemistry being the most recent addition, as described by Sherwen et al. (2016b). In this work we use global simulations run at a spatial resolution of $2^{\circ} \times 2.5^{\circ}$ with meteorological data from MERRA-2 (Gelaro et al., 2017). Whilst $2^{\circ} \times 2.5^{\circ}$ is a relatively coarse model resolution, we do not believe that there is any significant sub-grid-scale correlation between tropospheric ozone concentration and seasurface $\mathrm{I}^{-}$concentration; therefore this should not result in a resolution dependence. We run simulations for 2006-2008, 2013 and 2014 so that field observations are compared with the appropriate meteorology. Analysis of the sensitivity of the ozone deposition velocity to its controlling factors uses model runs for 2014. For the analysis of the impact on atmospheric composition, a 1-year "spin-up" was used to allow the tropospheric composition to reach equilibrium before the subsequent analysis year.

As with many other atmospheric chemistry and transport models, the dry deposition in GEOS-Chem uses a resistancein-series scheme based on that of Wesely (1989). The details of this implementation are described by Wang et al. (1998). For terrestrial land types, the dry deposition in GEOS-Chem is generally consistent with observations (Silva and Heald, 2018).

We follow the Luhar et al. (2018) methodology, and as shown in Eq. (3), this requires the calculation of $\alpha, D, k,\left[I^{-}\right]$and $\delta_{\mathrm{m}}$. Where these require the sea surface temperature $(\mathrm{K}), T$, we use the skin temperature from the MERRA-2 meteorological fields.

We use the dimensionless solubility of ozone in water $\alpha$ from Morris (1988).

$\alpha=10^{-0.25-0.013(T-273.16)}$

We use the diffusivity $D\left(\mathrm{~m}^{2} \mathrm{~s}^{-1}\right)$ from Johnson and Davis (1996).

$D=1.1 \times 10^{-6} \exp \left(\frac{-1896}{T}\right)$

The temperature-dependent $k\left(\mathrm{M}^{-1} \mathrm{~s}^{-1}\right)$ for the aqueous phase reactions between ozone and iodide is from Magi et al. (1997).

$k=\exp \left(\frac{-8772.2}{T}+51.5\right)$

The reaction-diffusion sub-layer thickness (m) is defined as

$\delta_{\mathrm{m}}=\sqrt{\frac{D}{a}}$

and the global ocean iodide concentration distribution $\left[\mathrm{I}^{-}\right]$ (M) is taken from the most recent global climatology (Sherwen et al., 2019).

The waterside friction velocity $u_{\mathrm{w}}^{*}\left(\mathrm{~m} \mathrm{~s}^{-1}\right)$ can be calculated from the MERRA-2 atmospheric friction velocity $u^{*}$ using Eq. (11), where $\rho_{\mathrm{a}}$ and $\rho_{\mathrm{w}}$ are the density of the atmosphere and seawater respectively. This assumes that drivers of atmospheric stress result in an equivalent oceanic stress 
(Fairall et al., 2007).

$u_{\mathrm{w}}^{*}=\sqrt{\frac{\rho_{\mathrm{a}}}{\rho_{\mathrm{w}}}} u^{*} \approx 0.0345 u^{*}$

Three significant differences exist in our choice of parameters compared to the work of Luhar et al. (2018). Firstly, we use the Sherwen et al. (2019) ocean iodide distributions, whereas they use MacDonald et al. (2014). Sherwen et al. (2019) is based on a recent collation of sea surface iodide observations (Chance et al., 2019) which are interpolated using a machine learning approach. MacDonald et al. (2014) is based on a more restrictive observational dataset and uses a simple temperature-based parameterization. Sherwen et al. (2019) calculate a global average sea-surface $\left[\mathrm{I}^{-}\right]$ of $105.8 \pm 45.6 \mathrm{nM}$, which is a significant increase from the global mean of $58.9 \pm 34.9 \mathrm{nM}$ found by MacDonald et al. (2014). Secondly, we include a variable thickness for the reaction-diffusion sub-layer (Eq. 10). Luhar et al. (2018) explored various options for this parameter and decided upon a fixed value of $\delta_{\mathrm{m}}\left(3.0 \times 10^{-6} \mathrm{~m}\right)$ as this gave the best fit of $v_{\mathrm{d}}$ to observations from Helmig et al. (2012). We decide to use the variable definition in our work as this is more physically based and produces comparable results in our simulations. However, it should be noted that using this definition of $\delta_{\mathrm{m}}$ results in terms cancelling in Eq. (6) such that $\lambda=1$. This thus simplifies Eq. (3) somewhat as $\sinh (1) \approx 1.175$ and $\cosh (1) \approx 1.543$. Some of the implications for different choices for $\delta_{\mathrm{m}}$ are explored in Luhar et al. (2018). Finally, we differentiate between salt and fresh water, using a salinity map from the World Ocean Atlas 2013 (Zweng et al., 2013). The new ozone deposition scheme is only applied to ocean water. Anywhere with water and a salinity below $20 \mathrm{PSU}$ or no salinity value (fresh water) is assigned a constant $r_{\mathrm{c}}=2000 \mathrm{~s} \mathrm{~m}^{-1}$. One further difference between this work and that of Luhar et al. (2018) is in the global chemistry transport model and its chemistry scheme, GEOS-Chem includes halogen chemistry which has a notable effect on tropospheric ozone (Sherwen et al., 2016b).

Any additional computational expense of implementing this improved $r_{\mathrm{c}}$ calculation will be small as the deposition velocity calculation remains a two-dimensional problem, unlike the chemistry or transport calculations which are three dimensional problems.

It would be possible to apply this method of calculating $r_{\mathrm{c}}$ to other chemical species, if the appropriate sink processes were understood, chemical kinetics available and concentrations of reactant species known. For this to be useful, the species would need to have a high dependence on $r_{c}$ (rather than the physical resistances), but also for dry deposition to form a substantial part of the species budget. It is not clear whether any species, other than $\mathrm{O}_{3}$, would meet these requirements.

\section{Impact of new parameterization on deposition}

\subsection{Change in global distribution of deposition velocities}

Figure 2 shows the annual average global distribution of oceanic ozone deposition velocity for both the standard model and the updated surface resistance scheme, along with the percentage difference between the two. Table 1 gives a statistical description of global ozone dry deposition in the model. The near-uniform value of $v_{\mathrm{d}}$ with the standard uniform surface resistance can be observed in Fig. 2a. The small variability in deposition velocity seen is driven by differences in the meteorology. This contrasts with the variability calculated with the new scheme (Fig. 2b). The two schemes also differ in the magnitude of the deposition velocities. The largest change occurs in the coolest waters towards the poles, with the Southern Ocean having a reduction of over $90 \%$ compared to the standard scheme, whereas the tropics can have as little as a $10 \%$ reduction. The distribution of $v_{\mathrm{d}}$ is similar to that shown in Luhar et al. (2018), despite our use of the variable thickness for the reactiondiffusion sub-layer and the use of the Sherwen et al. (2019) iodide. On an area-weighted basis, the deposition of ozone to the ocean surface is reduced from $0.0464 \mathrm{~cm} \mathrm{~s}^{-1}$ (25th and 75th percentiles of 0.0461 and $0.0471 \mathrm{~cm} \mathrm{~s}^{-1}$ respectively) to $0.0231 \mathrm{~cm} \mathrm{~s}^{-1}$ (25th and 75th percentiles of 0.0121 and $0.0303 \mathrm{~cm} \mathrm{~s}^{-1}$ respectively). This amounts to a halving of the mean ocean deposition velocity. The reduction of deposition velocity to the ocean results in a reduction of $17 \%$ in the global average deposition velocity (Table 1). The total annual loss of tropospheric ozone to dry deposition decreases by 104 to $758 \mathrm{Tg} \mathrm{yr}^{-1}$, substantially lower than the average of $978 \pm 127 \mathrm{Tg} \mathrm{yr}^{-1}$ from the multi-model comparison found by Hardacre et al. (2015) but comparable to the value obtained by Luhar et al. (2018) of $722 \pm 87.3 \mathrm{Tg} \mathrm{yr}^{-1}$. The seasonal changes in ozone oceanic deposition velocities from the new annual mean are shown in Fig. 3. This shows the response of the ozone deposition velocity to changes in sea-surface temperature, with the highest value in the summer for each hemisphere and the lowest values occurring in the winter. In the extra-tropical oceans, deposition velocities are predicted to vary by roughly $50 \%$ between summer and winter. Deposition velocities in the tropics remain relatively constant over the year.

\subsection{Comparison to observations}

Here we evaluate the modelled deposition velocities against the open-ocean measurements from Helmig et al. (2012), who measured ozone fluxes to the ocean surface using eddy covariance. These measurements are from a series of five cruises between 2006 to 2008 that took place in the Gulf of Mexico, eastern Pacific Ocean, western Atlantic Ocean and Southern Ocean (Fig. 4). These cruises were made in waters 
Table 1. Area-weighted annual average deposition velocity and deposition flux for 2014 by land type for ozone in GEOS-Chem using the default (constant) and new (variable) scheme for calculating $r_{\mathrm{c}}$. The 25 th and 75 th percentiles are the subscripts and superscripts respectively for each land type's deposition velocity. The average deposition velocities and 25 th and 75 th percentiles were calculated from monthly average model values for grid boxes containing $100 \%$ of the land type specified unless otherwise stated.

\begin{tabular}{|c|c|c|c|c|}
\hline \multirow[t]{2}{*}{ Land type } & \multicolumn{2}{|c|}{ Constant $r_{\mathrm{c}}$} & \multicolumn{2}{|c|}{ Variable $r_{\mathrm{c}}$} \\
\hline & $\mathrm{O}_{3} v_{\mathrm{d}}\left(\mathrm{cm} \mathrm{s}^{-1}\right)$ & $\begin{array}{r}\mathrm{O}_{3} \text { deposition flux } \\
\left(\mathrm{Tg} \mathrm{yr}^{-1}\right)\end{array}$ & $\mathrm{O}_{3} v_{\mathrm{d}}\left(\mathrm{cms}^{-1}\right)$ & $\begin{array}{r}\mathrm{O}_{3} \text { deposition flux } \\
\left(\mathrm{Tg} \mathrm{yr}^{-1}\right)\end{array}$ \\
\hline Land & $0.2370_{0.1486}^{0.2612}$ & 383 & $0.2370_{0.1486}^{0.2612}$ & 386 \\
\hline Ocean & $0.0464_{0.0461}^{0.0471}$ & 222 & $0.0231_{0.0121}^{0.0303}$ & 122 \\
\hline Mixed* & $0.1501_{0.0489}^{0.1785}$ & 255 & $0.1426_{0.0332}^{0.1755}$ & 248 \\
\hline Ice & $0.0098_{0.0094}^{0.0100}$ & 2 & $0.0098_{0.0094}^{0.0100}$ & 2 \\
\hline All & $0.0937_{0.0319}^{0.0582}$ & 862 & $0.0781_{0.0124}^{0.0460}$ & 758 \\
\hline
\end{tabular}

*Mixed is defined as any grid box containing less than $100 \%$ water and less than $100 \%$ land.

(a)

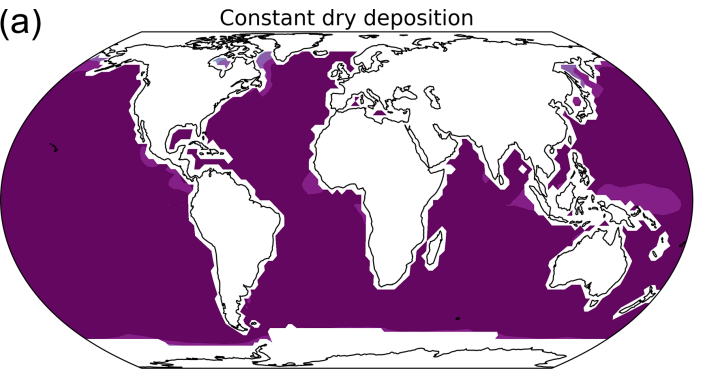

(b)

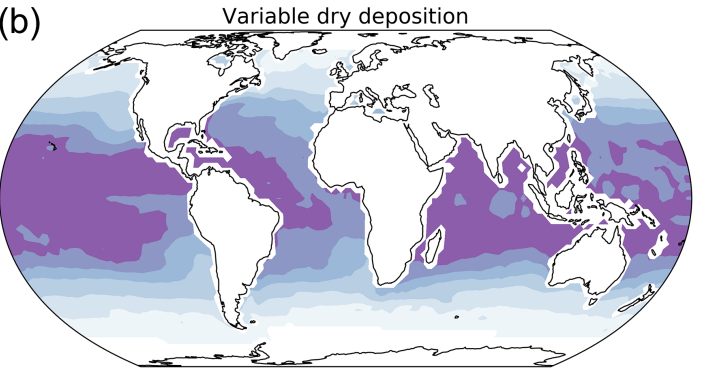

(c)

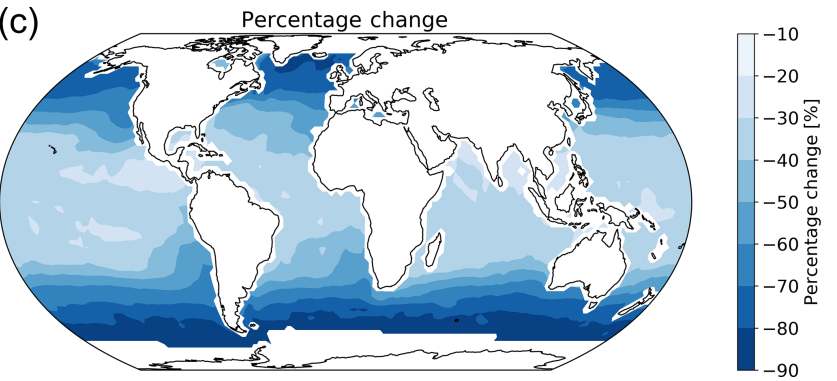

Figure 2. Annual average ozone deposition velocities for 2014 as calculated by GEOS-Chem using the default deposition scheme (a), the new parameterization (b) and the percentage change between the two schemes (c). A $2^{\circ} \times 2.5^{\circ}$ land mask has been applied to the deposition velocities to show only the deposition velocity to the ocean. of significantly different sea surface temperature (SST) and show a trend between deposition velocity and the SST. The comparisons between observations and model were made using daily average values with model output selected from grid boxes that the ship track passed through in that $24 \mathrm{~h}$ period. The old scheme (grey line) overestimates the rate of dry deposition substantially and fails to capture any of the temperature dependencies seen in the observations. The new scheme (black line) is a significant improvement, agreeing more with the magnitude and the temperature dependence of the observations. It should be noted that there are significant uncertainties in the measured deposition velocities at low values (Helmig et al., 2012). Combining all the measurements made by Helmig et al. (2012) and comparing to the model predictions for deposition velocity, the root mean square error for the model agreement was reduced from $0.04 \mathrm{~cm} \mathrm{~s}^{-1}$ using the default scheme to $0.01 \mathrm{~cm} \mathrm{~s}^{-1}$ using the new scheme. Whilst the overall agreement of the model with the observations has been improved, the model still fails to capture all of the variability of the deposition velocity measurements. This may be an issue with the resolution of the model $\left(2^{\circ} \times 2.5^{\circ}\right)$, which may fail to capture local conditions. Uncertainties in sea-surface iodide concentration or the lack of other sea-surface reactions (reaction between ozone and DOC) may also contribute.

\subsection{Sensitivity of new scheme}

We explore here the sensitivity of the new scheme to our choice of parameterization for $u_{\mathrm{w}}^{*}, \mathrm{I}^{-}, k, D$ and $\alpha$. Five model simulations were each run for a year, with only one of the parameters allowed to vary. When constrained, the value of each parameter was set to a representative value of the global average $(\alpha, D, k$ calculated with an SST of $289 \mathrm{~K}$, sea-surface iodide concentration of $106 \mathrm{nM}$ and $u_{\mathrm{w}}^{*}$ of $0.01 \mathrm{~m} \mathrm{~s}^{-1}$ ). A sixth model simulation was run with all $r_{\mathrm{c}}$ 

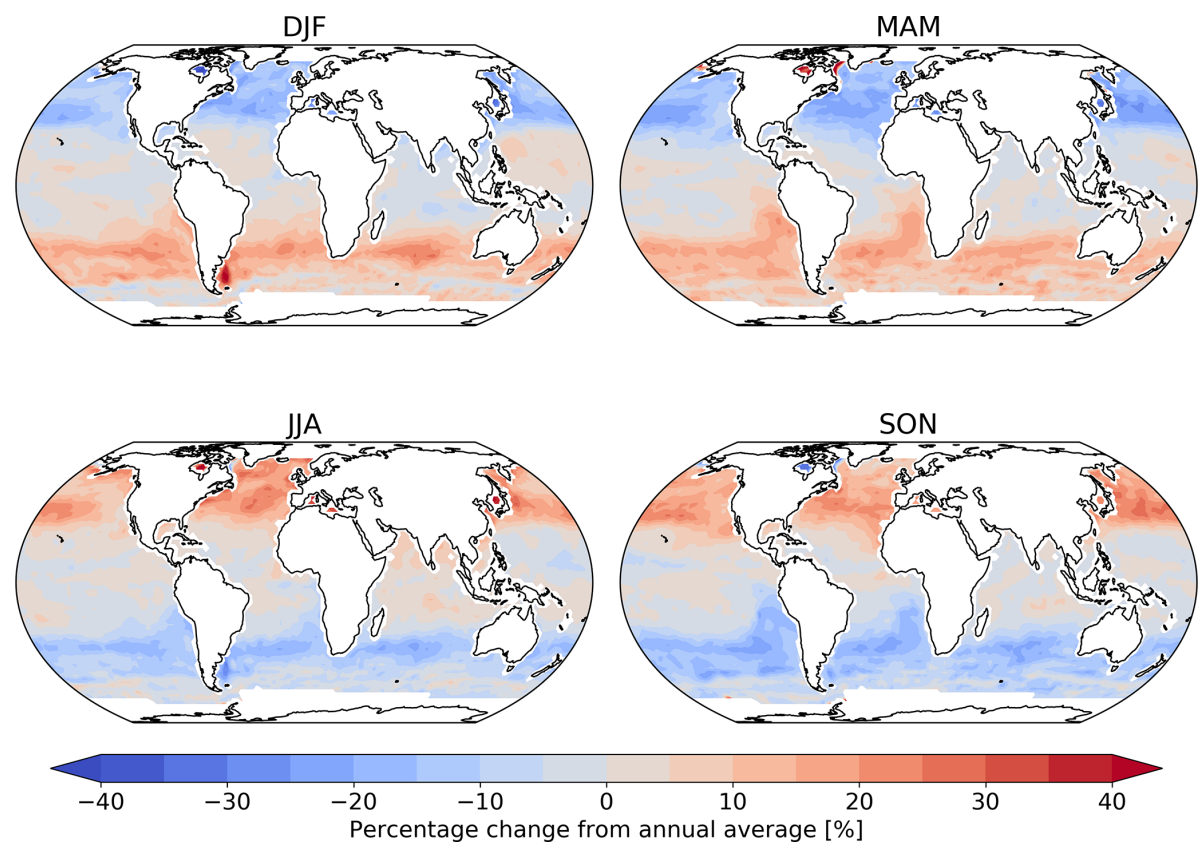

Figure 3. Percentage change from the annual mean deposition velocity for 2014 in December, January and February (DJF); March, April and May (MAM); June, July and August (JJA); and September, October and November (SON) for the new parameterization (shown in Fig. 2), demonstrating the deposition velocity responding to changes in sea-surface temperature and ocean $\mathrm{I}^{-}$concentration, with the lowest values of deposition velocity seen in the winter of each hemisphere. Land and ice grid boxes have been masked out.

(a)

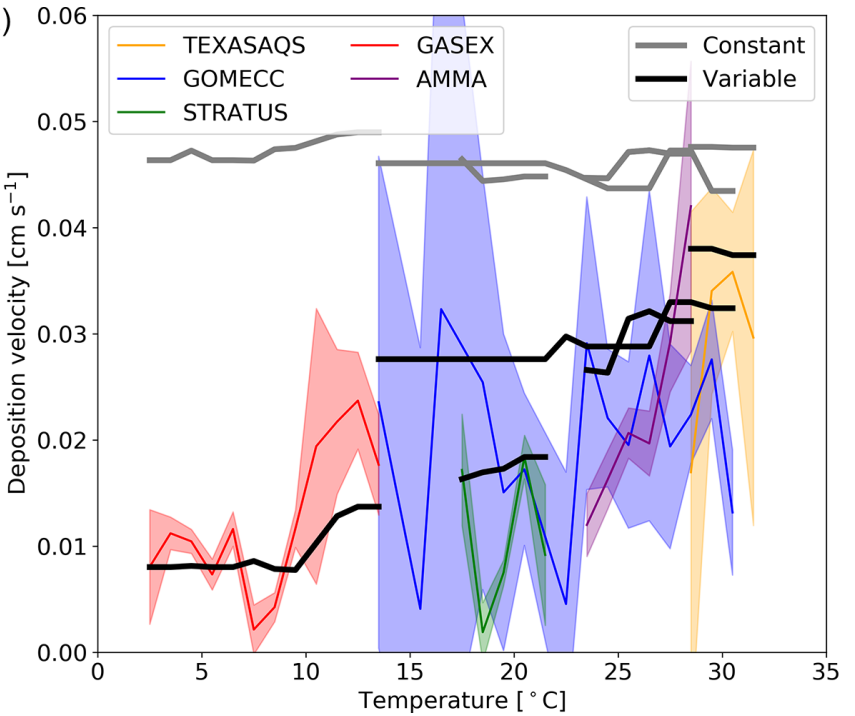

(b)

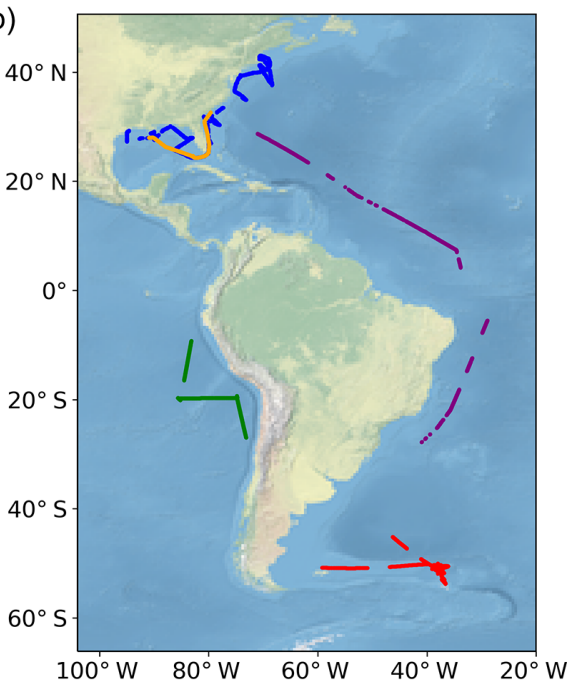

Figure 4. (a) The deposition velocities predicted by the model using the default (constant) value for $r_{\mathrm{c}}$ and the new (variable) parameterization of $r_{\mathrm{c}}$ compared against the five open-ocean cruise datasets of ozone deposition by Helmig et al. (2012). The solid lines represent the median of the deposition velocity for a $1^{\circ}$ temperature window, with the shaded region representing the 25 th to 75 th percentiles. (b) The locations along the cruise tracks where the ozone deposition has been compared.

parameters kept constant at these representative values. The resulting dependence of deposition velocity for each simulation is shown in Fig. 5 as a function of sea surface temperature. If all of the terms needed to calculate $r_{\mathrm{c}}$ are kept constant (top left) the oceanic deposition velocity does not vary with temperature. Similarly, if only the water side friction velocity is allowed to vary, no dependence on temperature is seen. Surprisingly the temperature dependence of the iodide concentration is not large, reflecting its square root dependence in the calculation of $r_{\mathrm{c}}$. The two most important 

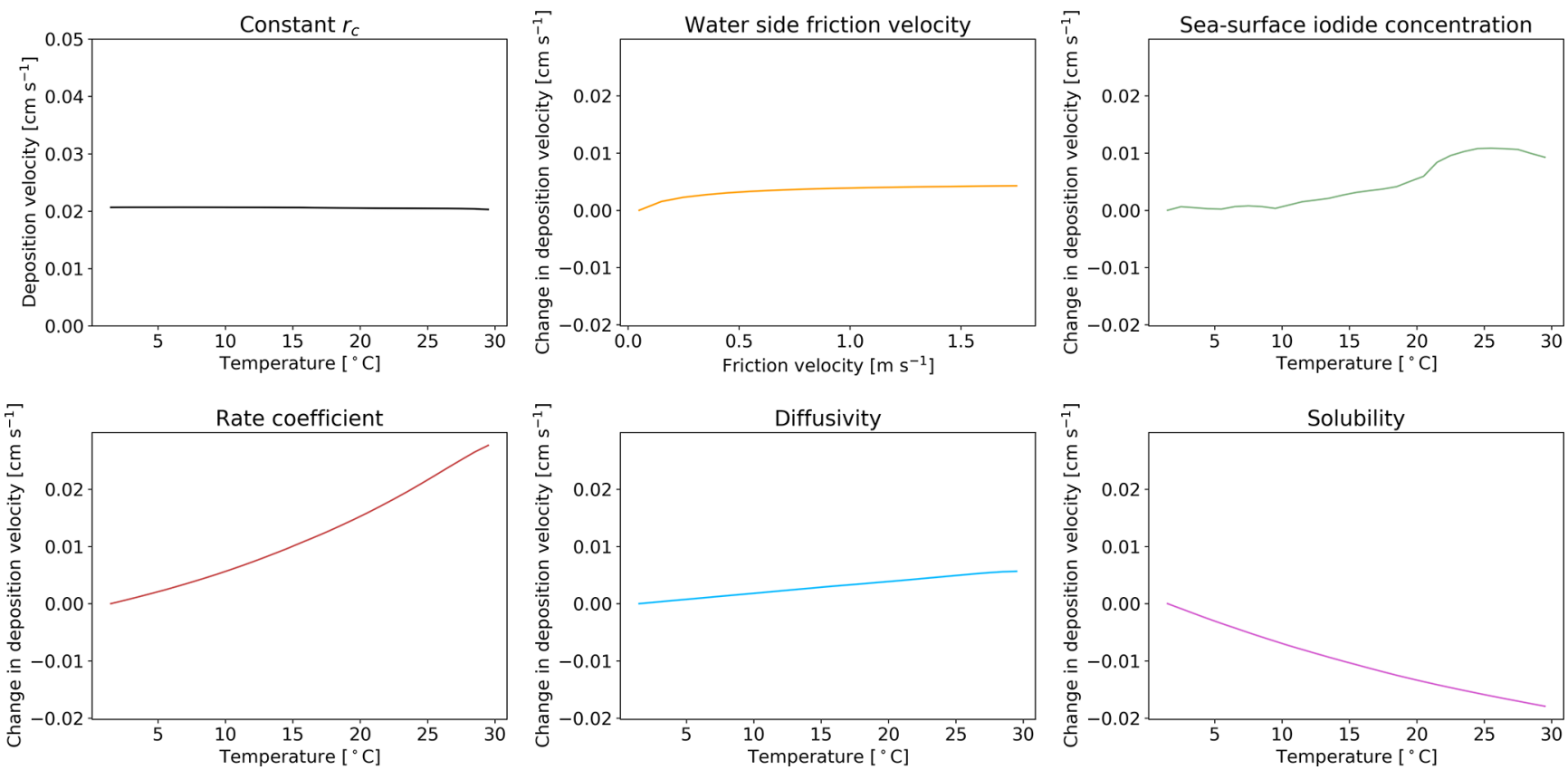

Figure 5. The response of deposition velocity to the variation of only a single parameter, with other parameters set to global average values. Sea-surface iodide concentration $\left[\mathrm{I}^{-}\right]$, rate coefficient $k$, diffusivity $D$ and solubility $\alpha$ are produced from global values averaged into $1 \mathrm{~K}$ temperature bins. Water side friction velocity $u_{\mathrm{W}}^{*}$ is averaged into $0.1 \mathrm{~m} \mathrm{~s}^{-1}$ friction velocity bins.

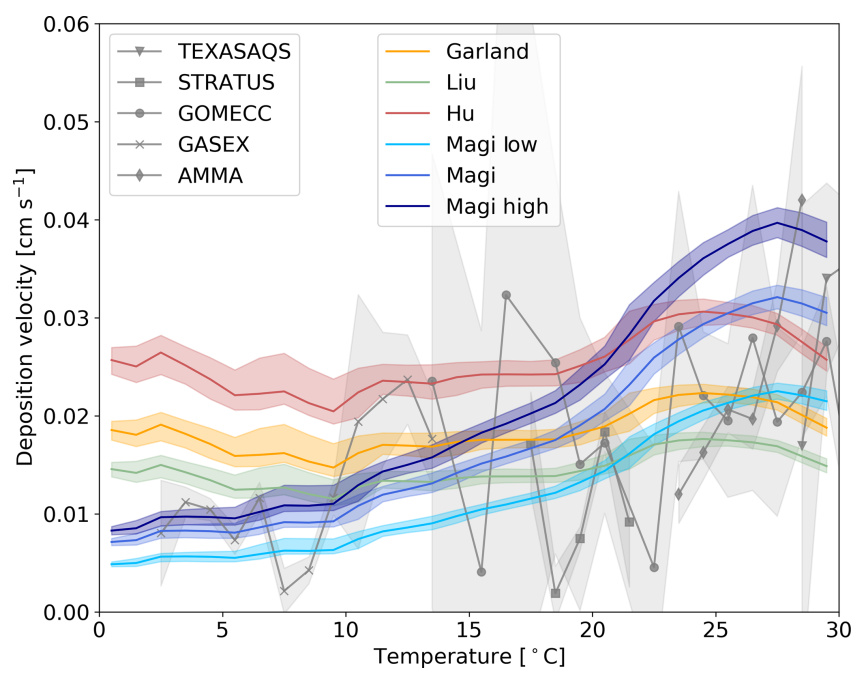

Figure 6. The response of deposition velocity to different laboratory measurements of $k$. Three are constant with respect to temperature (Garland et al., 1980; Liu et al., 2001; Hu et al., 1995) and the temperature-dependent parameterization of Magi et al. (1997), with two additional cases of $k$ based on the error range of the Magi et al. (1997) measurements (shown in Eqs. 13 and 12). Each function is produced from global values averaged into $1 \mathrm{~K}$ temperature bins, with the shaded region representing the 25 th to 75 th percentiles.

factors for giving the observed temperature dependence are $k$ and $\alpha$. Of these two terms, the dependence on rate coefficient carries the most uncertainty.
Magi et al. (1997) is the only temperature-dependent rate constant in the literature. Other studies are at single temperatures and show differences (Luhar et al., 2018). We explore the impact of these differences by running a number of simulations with different values of the rate constants (Fig. 6). We use the single temperature rate constants given by Garland et al. (1980) $\left(2.0 \times 10^{9} \mathrm{M}^{-1} \mathrm{~s}^{-1}\right.$ at $\left.298 \mathrm{~K}\right)$, Liu et al. (2001) $\left(1.2 \times 10^{9} \mathrm{M}^{-1} \mathrm{~s}^{-1}\right.$ at $\left.298 \mathrm{~K}\right)$ and $\mathrm{Hu}$ et al. (1995) $\left(4.0 \times 10^{9} \mathrm{M}^{-1} \mathrm{~s}^{-1}\right.$ at $\left.277 \mathrm{~K}\right)$. We also use the upper (Eq. 12) and lower (Eq. 13) estimates of Magi et al. (1997) (based on the reported error of the series of measurements).

$$
\begin{aligned}
& k=\exp \left(\frac{-9261.6}{T}+53.6\right) \\
& k=\exp \left(\frac{-8796.2}{T}+50.8\right)
\end{aligned}
$$

Figure 6 shows that the uncertainties in $k$ can substantially impact the modelled deposition velocity, with the difference between a temperature-invariant and temperature-dependent $k$ most notable. The temperature-independent rate constants do not correctly simulate the observed temperature variability in deposition velocity. The higher estimate from Magi et al. (1997) overestimates the deposition velocity in warm waters, with the lower estimate underestimating in cold waters. As discussed in Sect. 1 iodide is the dominant but not the only removal mechanism for ozone at the ocean surface. Given the upper and mid value of the Magi et al. (1997) rate constants there does not appear to be much potential for other oceanic components to play an important role. On the other 
hand, if the lower values of the Magi et al. (1997) rate constant were correct, this would allow for the inclusion of additional reactions (such as that of ozone with dissolved organic carbon) in the model parameterization without overestimating deposition velocities.

\section{Atmospheric impact}

\subsection{Global impacts}

The net decrease in deposition of ozone to the surface results in an increase in both surface and column ozone mixing ratios (Fig. 7). The greatest increase in ozone concentration occurs in the boundary layer, with the magnitude of the change decreasing with altitude through the troposphere. The largest increases in the ozone mixing ratio is above the oceans, most notably the extra-tropics, with the Southern Hemisphere extra-tropics being the area of greatest increase. The increase in surface ozone concentration becomes small over land. Surface grid boxes that experience a $10 \%$ increase or greater in ozone mixing ratio represent $34 \%$ of the total surface grid box count. Table 2 gives diagnostics on the oxidative capacity of the troposphere for both the old and new schemes. The increase in ozone mixing ratio shown in Fig. 7 equates to an increase in the tropospheric ozone burden of $4 \mathrm{Tg} \mathrm{yr}^{-1}(1.2 \%)$. This affects the global chemical production and loss of $\mathrm{O}_{3}$; however, these changes are globally minimal, at $-0.6 \%$ and $1.2 \%$, respectively.

Another consequence of the increased ozone mixing ratio is a small increase in global mean $\mathrm{OH}$ concentration of $0.9 \%$ (Table 2), resulting in a decrease in the tropospheric methane lifetime from 8.3 to 8.2 years.

Seasonal variations are also observed in the changes in surface ozone mixing ratio due to the new scheme (Fig. 8). The largest increase is observed over the oceans during the winter of each hemisphere due to both the lower deposition velocity that occurs in colder waters and due to the dry deposition playing a larger role in the ozone budget when photolysis is at a seasonal low.

\subsection{Regional impacts}

To assess the predictions of surface ozone mixing ratios in the model, comparisons were made with surface ozone measurements from a number of World Meteorological Organization (WMO) Global Atmosphere Watch (GAW; http:// www.wmo.int/pages/prog/arep/gaw/gaw_home_en.html, accessed through EBAS: http://ebas.nilu.no/, last access: 20 Feburary 2020; the database infrastructure is operated by NILU - Norwegian Institute for Air Research) sites around the world (Fig. 9, shown south to north).

The largest area of change in surface ozone in the model is in the Southern Ocean. GAW sites in this region (Cape Grim, Ushuaia and Neumayer) show increases in ozone prediction during their winter-spring, with the increase most notable in
Table 2. Summary of change to atmospheric oxidative capacity for GEOS-Chem using the default (constant) scheme for calculating $r_{\mathrm{c}}$ and the new scheme (variable) for 2014.

\begin{tabular}{lrr}
\hline & Constant & Variable \\
\hline Troposphere $\mathrm{O}_{3}$ burden $(\mathrm{Tg})$ & 324 & 328 \\
Net chemical $\mathrm{O}_{3}$ rate $\left(\mathrm{Tg} \mathrm{yr}^{-1}\right)^{*}$ & 450 & 363 \\
$\mathrm{O}_{X}$ production rate $\left(\mathrm{Tg} \mathrm{yr}^{-1}\right)^{*}$ & 5048 & 5017 \\
$\mathrm{O}_{X}$ loss rate $\left(\mathrm{Tg} \mathrm{yr}^{-1}\right)^{*}$ & 4598 & 4654 \\
$\mathrm{O}_{3}$ loss to deposition $\left(\mathrm{Tg} \mathrm{yr}^{-1}\right)$ & 862 & 758 \\
Stratospheric $\mathrm{O}_{3}$ flux $\left(\mathrm{Tg} \mathrm{yr}^{-1}\right)$ & 412 & 395 \\
\hline Global annual mean $\mathrm{OH}\left(10^{6}\right.$ molec. cm & -3 \\
Global $\mathrm{CH}_{4}$ lifetime $($ years $)$ & 1.17 & 1.18 \\
\end{tabular}

* Here, $\mathrm{OX}$ is defined as $\mathrm{O}_{3}+\mathrm{NO}_{2}+\mathrm{NO}_{3}+\mathrm{HNO}_{4}+\mathrm{HNO}_{3}+\mathrm{N}_{2} \mathrm{O}_{5}+\mathrm{BrO}+\mathrm{HOBr}+$ $\mathrm{BrNO}_{2}+\mathrm{BrNO}_{3}+\mathrm{IO}+\mathrm{HOI}+\mathrm{IONO}+\mathrm{IONO}_{2}+\mathrm{OIO}+\mathrm{I}_{2} \mathrm{O}_{2}+\mathrm{I}_{2} \mathrm{O}_{3}+\mathrm{I}_{2} \mathrm{O}_{4} \mathrm{ClO}+\mathrm{HOCl}$ $+\mathrm{ClNO}_{2}+\mathrm{ClNO}_{3}+\mathrm{Cl}_{2} \mathrm{O}_{2}+\mathrm{OClO}+\mathrm{PAN}$ (peroxyacetylnitrate) $+\mathrm{PMN}$

(peroxymethacryloylnitrate) + PPN (peroxypropionylnitrate) + MPN (methyl peroxy nitrate) + ETHLN (ethanal nitrate) $+\mathrm{R}_{4} \mathrm{~N}_{2}\left(\geq \mathrm{C}_{4}\right.$ alkylnitrates) + R4N1 $\left(\mathrm{RO}_{2}\right.$ from $\left.\mathrm{R}_{4} \mathrm{~N}_{2}\right)$ + isoprene nitrate (ISN1, ISOPNB, ISOPND, ISNP) + peroxy radical from isoprene (ISNOOA, ISNOOB, ISNOHOO) + MACRN (methacrolein nitrate) + MVKN (nitrate from methyl vinyl keytone) + PROPNN (propanone nitrate) $+\mathrm{O}_{2} \mathrm{NOCH}_{2} \mathrm{C}(\mathrm{OO})$ $\left(\mathrm{CH}_{3}\right) \mathrm{CH}=\mathrm{CH}_{2}(\mathrm{INO} 2)+\mathrm{O}_{2} \mathrm{NOCH}_{2} \mathrm{C}(\mathrm{OOH})\left(\mathrm{CH}_{3}\right) \mathrm{CH}=\mathrm{CH}_{2}(\mathrm{INPN})+\mathrm{HOCH}_{2} \mathrm{C}$ $\left(\mathrm{ONO}_{2}\right)\left(\mathrm{CH}_{3}\right) \mathrm{CHO}(\mathrm{MAN} 2)+\mathrm{PRN} 1\left(\mathrm{RO}_{2}\right.$ from propene $\left.+\mathrm{NO}_{3}\right)+\mathrm{PRPN}$ (peroxide from PRN1) + MACRNO2 (result of $\left.\mathrm{HOCH}_{2} \mathrm{C}\left(\mathrm{ONO}_{2}\right)\left(\mathrm{CH}_{3}\right) \mathrm{CHO}+\mathrm{OH}\right)$. For further details on this tagging see the GEOS-Chem wiki

http://wiki.seas.harvard.edu/geos-chem/index.php/FlexChem (last access: 20 February 2020).

Table 3. Root mean square error (RMSE) of the model with the default (constant) scheme for $r_{\mathrm{c}}$ and the new scheme (variable) when compared to the observations at GAW sites calculated from monthly mean values of observations and model predictions.

\begin{tabular}{lrr}
\hline GAW site & $\begin{array}{r}\text { Constant RMSE } \\
(\text { ppbv })\end{array}$ & $\begin{array}{r}\text { Variable RMSE } \\
(\text { ppbv })\end{array}$ \\
\hline Villum & 4.2 & 4.5 \\
Mace Head & 5.0 & 3.4 \\
Cape Verde & 2.6 & 2.0 \\
Cape Grim & 3.5 & 1.5 \\
Ushuaia & 2.7 & 2.0 \\
Neumayer & 5.6 & 2.8 \\
\hline
\end{tabular}

the Antarctic site of Neumayer. Previous works in GEOSChem by Schmidt et al. (2016) and Sherwen et al. (2016a) as well as inter-model comparison with ozonesonde observations by Young et al. (2013) show a low bias of GEOSChem and other models in the Southern Ocean and Antarctic region. The increased surface ozone mixing ratio brings the model predictions closer to the observations in the Southern Ocean region (Fig. 9), as well as the reductions in root mean square error (RMSE), a measure of disagreement between the model and observations, (Table 3 ) which is reduced by an average of $44 \%$ across these three locations. Whilst there are considerable improvements in the Antarctic location of Neumayer, surface ozone demonstrate a "lag" in responding to Antarctic spring-summer. The model also fails to capture the springtime halogen-induced ozone depletion events that are observed at Neumayer. 

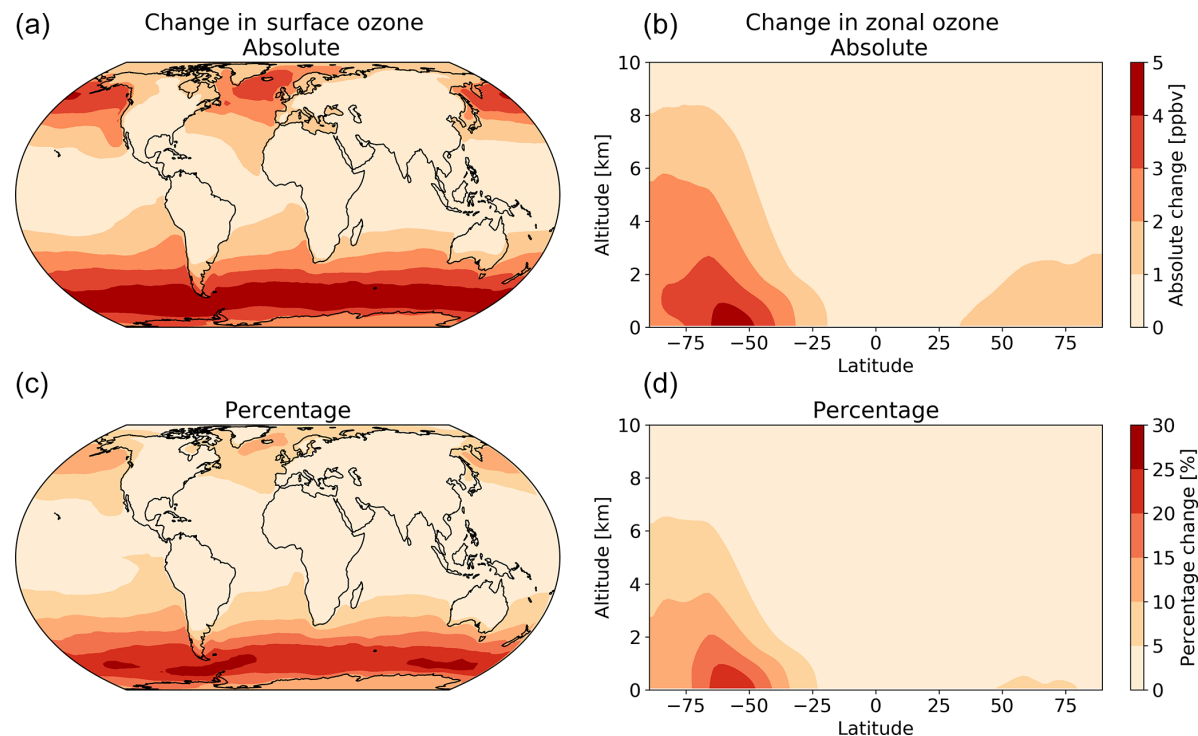

Figure 7. The annual absolute (a, b) and percentage (c, d) change in surface and column ozone mixing ratios for 2014 between the model using the default (constant) and new (variable) parameterization for $r_{\mathrm{c}}$. The largest changes occur in the surface levels of the model, especially in higher latitudes, with the Southern Ocean boundary layer representing the area experiencing the most annual average change between the two model runs.
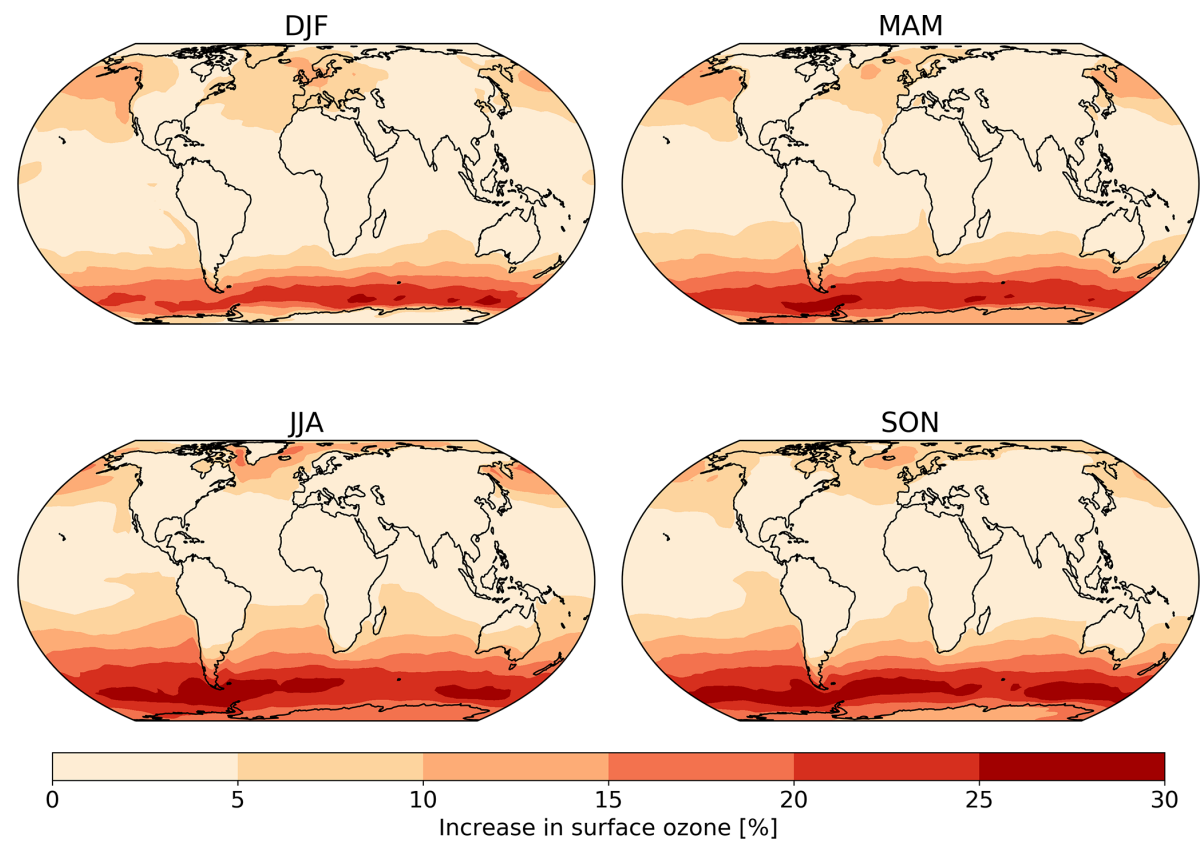

Figure 8. The absolute seasonal surface ozone mixing ratio change for 2014 between the model runs using the default (constant) and new (variable) parameterization for $r_{\mathrm{c}}$.

A comparison to a clean tropical location is made using the GAW site in Cabo Verde. Tropical waters are where there has been the least change in ozone deposition velocity, as well as the least increase in ozone mixing ratio both annually and seasonally. Whilst there is a slight increase in predicted ozone compared to the observations at Cape Verde, both the model using the old and the model using new schemes for ozone deposition are within the error of the observations, and there is a small reduction in RMSE.

Mace Head, Ireland, offers an evaluation of model performance in a mid-latitude inflow region, and the inflow of air from the North Atlantic at this site is the dominant component into Europe. Comparing the increase to the observations 

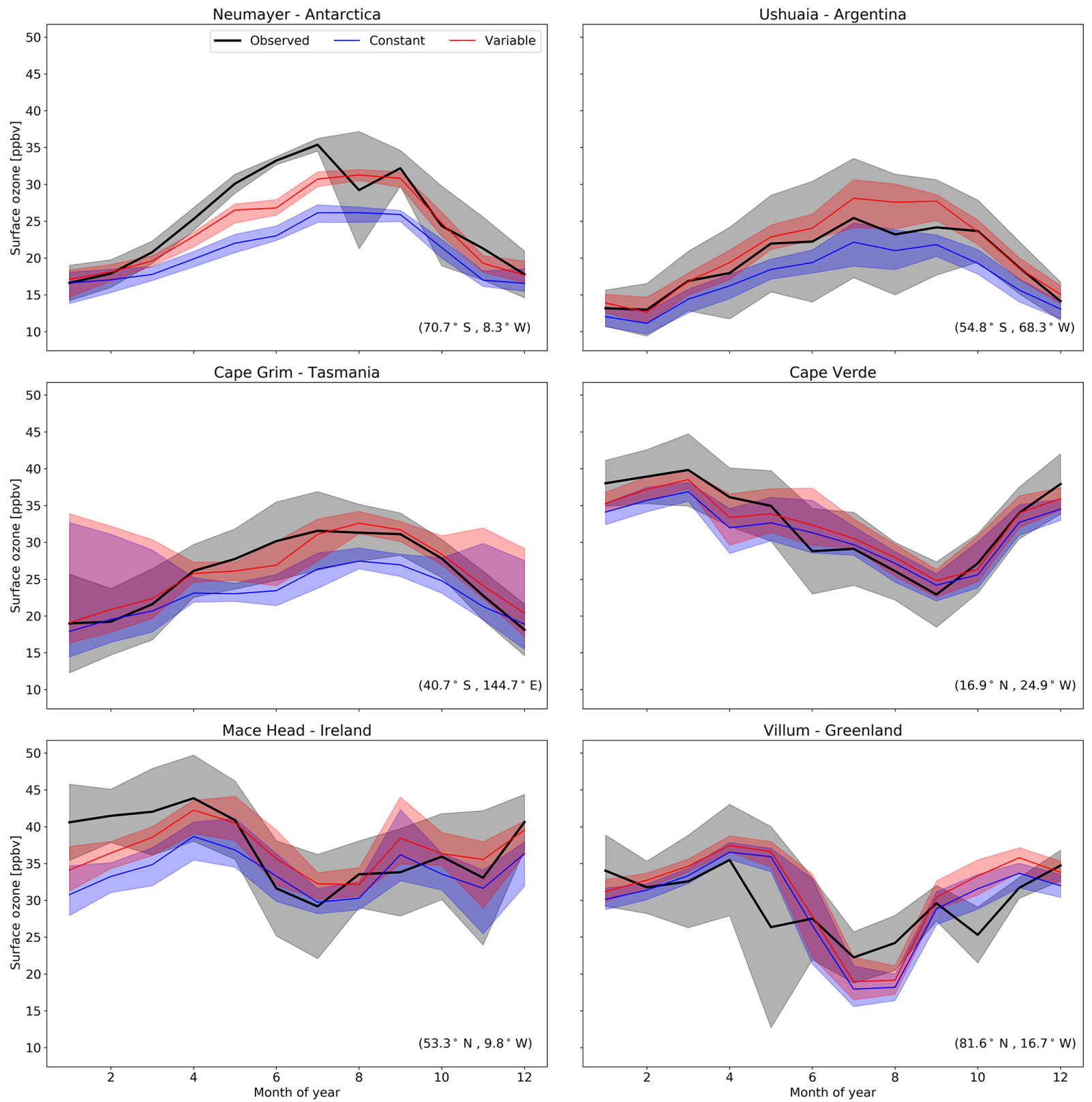

Figure 9. Predictions and observations of monthly average surface ozone mixing ratio for 2014 from the model using the default (constant) and new (variable) parameterization for $r_{\mathrm{c}}$ for six GAW stations (with the latitude and longitude for each station at the bottom right), with the shaded region representing the 25 th to 75 th percentiles.

at Mace Head the improvement is notable, with the model error reduced by approximately $30 \%$.

The most northerly of the GAW sites in this comparison is the Villum research station in Greenland. There is a minimal increase in predicted surface ozone $(\sim 1 \mathrm{ppbv})$ at this site and the resulting RMSE (Table 3) shows for Villum an increase of $0.3 \mathrm{ppbv}$ with the new parameterization. The observations at Villum also show springtime ozone depletion events and, as with Neumayer, the model fails to capture this.
Overall, the majority of GAW sites show improved comparisons with observations due to the implementation of the new $r_{\mathrm{c}}$ scheme and, supporting that, this change is an improvement to the model.

\section{Conclusions}

We have implemented a new scheme for the deposition of ozone to the ocean into the GEOS-Chem chemistry transport model based on the work of Luhar et al. (2018). This con- 
siders the physical and chemical controls of ozone loss in the sea surface. In contrast to Luhar et al. (2018), our work has used a variable surface micro-layer depth and the higher ocean iodide concentrations from Sherwen et al. (2019). The new scheme results in a halving of the global mean ozone deposition velocity to the ocean, leading to a small increase in the global tropospheric ozone burden and some regional increases in ozone mixing ratios of up to $30 \%$ in the high latitude boundary layer, notably around the Southern Ocean. The new scheme improves comparisons between the model and observations in oceanic regions. The increase in tropospheric ozone concentration also has a minor effect on the global mean $\mathrm{OH}$ and $\mathrm{CH}_{4}$ lifetimes.

The new parameterization improves comparisons between the model and observed oceanic dry deposition velocities. However, no account has been made of potential additional processes such as the reaction of $\mathrm{O}_{3}$ with DOC, DMS and bromide at the ocean surface. Uncertainties in the rate constant for the reaction between $\mathrm{I}^{-}$and $\mathrm{O}_{3}$ could allow room for such additional reactions to play a role. Reduced uncertainty in the temperature-dependent rate constant for this reaction would be useful. In addition it seems likely that the interaction between DOC and ozone would be complex. It seems likely that some compounds will act as deposition enhancers, whilst others may act as inhibitors (Martino et al., 2012; Shaw and Carpenter, 2013). Further lab, field and modelling studies will be required to better constrain this.

Code availability. GEOS-Chem version 12.1 .1 was used in this project: https://doi.org/10.5281/zenodo.2249246 (The International GEOS-Chem User Community, 2018). This code will be available from version 12.8 of GEOS-Chem onwards and can be found at https://github.com/geoschem/geos-chem/tree/master. Code is also available on request.

Author contributions. RJP performed the model development, ran the simulations and analysed the output. MJE, LJC and RJP developed the project. TS assisted in model development. DH provided ozone deposition data. The paper was written by RJP with contributions from all co-authors.

Competing interests. The authors declare that they have no conflict of interest.

Acknowledgements. We thank WMO GAW and the individual sites that make up this network, for the availability of the surface ozone data.

This project was undertaken on the Viking Cluster, which is a high-performance computing facility provided by the University of York. We are grateful for computational support from the University of York High Performance Computing service, Viking and the Research Computing team.
Ryan J. Pound thanks NERC SPHERES DTP (NE/L002574/1) for funding his PhD studies.

Lucy J. Carpenter, Mat J. Evans and Tomás Sherwen are thankful for funding from Natural Environment Research Council (NERC) through the grant "Iodide in the ocean: distribution and impact on iodine flux and ozone loss" (NE/N009983/1)

Lucy J. Carpenter acknowledges funding from the European Research Council (ERC) under the European Union's horizon 2020 programme (grant agreement no. 833290)

Financial support. This research has been supported by the Natural Environment Research Council (grant no. NE/L002574/1).

Review statement. This paper was edited by Frank Dentener and reviewed by two anonymous referees.

\section{References}

Bariteau, L., Helmig, D., Fairall, C. W., Hare, J. E., Hueber, J., and Lang, E. K.: Determination of oceanic ozone deposition by shipborne eddy covariance flux measurements, Atmos. Meas. Tech., 3, 441-455, https://doi.org/10.5194/amt-3-441-2010, 2010.

Bey, I., Jacob, D. J., Yantosca, R. M., Logan, J. A., Field, B. D., Fiore, A. M., Li, Q., Liu, H. Y., Mickley, L. J., and Schultz, M. G.: Global modeling of tropospheric chemistry with assimilated meteorology: Model description and evaluation, J. Geophys. Res.-Atmos., 106, 23073-23095, https://doi.org/10.1029/2001JD000807, 2001.

Carpenter, L., MacDonald, S., Shaw, M., Kumar, R., Saunders, R., Parthipan, R., Wilson, J., and Plane, J.: Atmospheric iodine levels influenced by sea surface emissions of inorganic iodine, Nat. Geosci., 6, 108-111, https://doi.org/10.1038/ngeo1687, 2013.

Chance, R., Tinel, L., Sherwen, T., Baker, A., Bell, T., Brindle, J., Campos, M., Croot, P., Ducklow, H., He, P., Hoogakker, B., Hopkins, F., Hughes, C., Jickells, T., Loades, D., Macaya, D., Mahajan, A., Malin, G., Phillips, D., Sinha, A., Sarkar, A., Roberts, I., Roy, R., Song, X., Winklebauer, H., Wuttig, K., Yang, M., Zhou, P., and Carpenter, L.: Global sea-surface iodide observations, 1967-2018, Sci. Data, 6, 286, https://doi.org/10.1038/s41597019-0288-y, 2019.

Chang, W., Heikes, B., and Lee, M.: Ozone deposition to the sea surface:chemical enhancement and wind speed dependence, Atmos. Environ., 38, 1053-1059, https://doi.org/10.1016/j.atmosenv.2003.10.050, 2004.

Fairall, C. W., Helmig, D., Ganzeveld, L., and Hare, J.: Waterside turbulence enhancement of ozone deposition to the ocean, Atmos. Chem. Phys., 7, 443-451, https://doi.org/10.5194/acp-7443-2007, 2007.

Fowler, D., Amann, M., Anderson, R., Ashmore, M., Cox, P., Depledge, M., Derwent, D., Grennfelt, P., Hewitt, N., Hov, O., Jenkin, M., Kelly, F., Liss, P., Pilling, M., Pyle, J., Slingo, J., and Stevenson, D.: Ground-level ozone in the 21 st century: future trends, impacts and policy implications, RS1276 ed., The Royal Society, London, 132 p., Royal Society Policy Document 15/08, 2008. 
Ganzeveld, L., Helmig, D., Fairall, C., Hare, J., and Pozzer, A.: Atmosphere-ocean ozone exchange: A global modeling study of biogeochemical, atmospheric, and waterside turbulence dependencies, Global. Biogeochem. Cy., 23, 4, https://doi.org/10.1029/2008GB003301, 2009.

Garland, J. A. and Curtis, H.: Emission of iodine from the sea surface in the presence of ozone, J. Geophys. Res.-Oceans, 86, 3183-3186, https://doi.org/10.1029/JC086iC04p03183, 1981.

Garland, J. A., Elzerman, A. W., and Penkett, S. A.: The mechanism for dry deposition of ozone to seawater surfaces, J. Geophys. Res.-Oceans, 85, 7488-7492, https://doi.org/10.1029/JC085iC12p07488, 1980.

Gelaro, R., McCarty, W., Suárez, M. J., Todling, R., Molod, A., Takacs, L., Randles, C. A., Darmenov, A., Bosilovich, M. G., Reichle, R., Wargan, K., Coy, L., Cullather, R., Draper, C., Akella, S., Buchard, V., Conaty, A., da Silva, A. M., Gu, W., Kim, G.K., Koster, R., Lucchesi, R., Merkova, D., Nielsen, J. E., Partyka, G., Pawson, S., Putman, W., Rienecker, M., Schubert, S. D., Sienkiewicz, M., and Zhao, B.: The Modern-Era Retrospective Analysis for Research and Applications, Version 2 (MERRA-2), J. Climate, 30, 5419-5454, https://doi.org/10.1175/JCLI-D-160758.1, 2017.

Hardacre, C., Wild, O., and Emberson, L.: An evaluation of ozone dry deposition in global scale chemistry climate models, Atmos. Chem. Phys., 15, 6419-6436, https://doi.org/10.5194/acp15-6419-2015, 2015.

Hayase, S., Yabushita, A., Kawasaki, M., Enami, S., Hoffmann, M. R., and Colussi, A. J.: Heterogeneous Reaction of Gaseous Ozone with Aqueous Iodide in the Presence of Aqueous Organic Species, J. Phys. Chem. A, 114, 6016-6021, https://doi.org/10.1021/jp101985f, 2010.

Helmig, D., Lang, E. K., Bariteau, L., Boylan, P., Fairall, C. W., Ganzeveld, L., Hare, J. E., Hueber, J., and Pallandt, M.: Atmosphere-ocean ozone fluxes during the TexAQS 2006, STRATUS 2006, GOMECC 2007, GasEx 2008, and AMMA 2008 cruises, J. Geophys. Res.-Atmos., 117, D4, https://doi.org/10.1029/2011JD015955, 2012.

Hu, J. H., Shi, Q., Davidovits, P., Worsnop, D. R., Zahniser, M. S., and Kolb, C. E.: Reactive Uptake of $\mathrm{Cl} 2(\mathrm{~g})$ and $\mathrm{Br} 2(\mathrm{~g})$ by Aqueous Surfaces as a Function of Br- and I- Ion Concentration: The Effect of Chemical Reaction at the Interface, J. Phys. Chem., 99, 8768-8776, https://doi.org/10.1021/j100021a050, 1995.

IPCC: Climate Change 2013: The Physical Science Basis, Contribution of Working Group I to the Fifth Assessment Report of the Intergovernmental Panel on Climate Change, edited by: Stocker, T., Qin, D., Plattner, G., Tignor, M., Allen, S., Boschung, J., Nauels, A., Xia, Y., Bex, V., and Midgley, P., 2013.

Johnson, P. N. and Davis, R. A.: Diffusivity of Ozone in Water, J. Chem. Eng. Data, 41, 1485-1487, https://doi.org/10.1021/je9602125, 1996.

Liu, Q., Schurter, L. M., Muller, C. E., Aloisio, S., Francisco, J. S., and Margerum, D. W.: Kinetics and Mechanisms of Aqueous Ozone Reactions with Bromide, Sulfite, Hydrogen Sulfite, Iodide, and Nitrite Ions, Inorg. Chem., 40, 4436-4442, https://doi.org/10.1021/ic000919j, 2001.

Luhar, A. K., Galbally, I. E., Woodhouse, M. T., and Thatcher, M.: An improved parameterisation of ozone dry deposition to the ocean and its impact in a global climate-chemistry model, At- mos. Chem. Phys., 17, 3749-3767, https://doi.org/10.5194/acp17-3749-2017, 2017.

Luhar, A. K., Woodhouse, M. T., and Galbally, I. E.: A revised global ozone dry deposition estimate based on a new two-layer parameterisation for air-sea exchange and the multi-year MACC composition reanalysis, Atmos. Chem. Phys., 18, 4329-4348, https://doi.org/10.5194/acp-18-4329-2018, 2018.

MacDonald, S. M., Gómez Martín, J. C., Chance, R., Warriner, S., Saiz-Lopez, A., Carpenter, L. J., and Plane, J. M. C.: A laboratory characterisation of inorganic iodine emissions from the sea surface: dependence on oceanic variables and parameterisation for global modelling, Atmos. Chem. Phys., 14, 5841-5852, https://doi.org/10.5194/acp-14-5841-2014, 2014.

Magi, L., Schweitzer, F., Pallares, C., Cherif, S., Mirabel, P., and George, C.: Investigation of the Uptake Rate of Ozone and Methyl Hydroperoxide by Water Surfaces, J. Phys. Chem. A, 101, 4943-4949, https://doi.org/10.1021/jp970646m, 1997.

Malley, C. S., Henze, D. K., Kuylenstierna, J. C., Vallack, H. W., Davila, Y., Anenberg, S. C., Turner, M. C., and Ashmore, M. R.: Updated Global Estimates of Respiratory Mortality in Adults $\geq 30$ Years of Age Attributable to LongTerm Ozone Exposure, Environ. Health Persp., 125, 087021, https://doi.org/10.1289/EHP1390, 2017.

Martino, M., Lézé, B., Baker, A., and Liss, P.: Chemical controls on ozone deposition to water, Geophys. Res. Lett., 39, L05809, https://doi.org/10.1029/2011GL050282, 2012.

Morris, J.: The aqueous solubility of ozone - A review, Ozone news, 1, 14-16, 1988.

Sakamoto, Y., Yabushita, A., Kawasaki, M., and Enami, S.: Direct Emission of $\mathrm{I}_{2}$ Molecule and IO Radical from the Heterogeneous Reactions of Gaseous Ozone with Aqueous Potassium Iodide Solution, J. Phys. Chem. A, 113, 7707-7713, https://doi.org/10.1021/jp903486u, 2009.

Sarwar, G., Kang, D., Foley, K., Schwede, D., and Gantt, B.: Technical note: Examining ozone deposition over seawater, Atmos. Environ., 141, 255-262, https://doi.org/10.1016/j.atmosenv.2016.06.072, 2016.

Schmidt, J. A., Jacob, D. J., Horowitz, H. M., Hu, L., Sherwen, T., Evans, M. J., Liang, Q., Suleiman, R. M., Oram, D. E., Le Breton, M., Percival, C. J., Wang, S., Dix, B., and Volkamer, R.: Modeling the observed tropospheric BrO background: Importance of multiphase chemistry and implications for ozone, $\mathrm{OH}$, and mercury, J. Geophys. Res.-Atmos., 121, 11819-11835, https://doi.org/10.1002/2015JD024229, 2016.

Shaw, M. D. and Carpenter, L. J.: Modification of Ozone Deposition and $\mathrm{I}_{2}$ Emissions at the Air-Aqueous Interface by Dissolved Organic Carbon of Marine Origin, Environ. Sci. Technol., 47, 10947-10954, https://doi.org/10.1021/es4011459, 2013.

Sherwen, T., Evans, M. J., Carpenter, L. J., Andrews, S. J., Lidster, R. T., Dix, B., Koenig, T. K., Sinreich, R., Ortega, I., Volkamer, R., Saiz-Lopez, A., Prados-Roman, C., Mahajan, A. S., and Ordóñez, C.: Iodine's impact on tropospheric oxidants: a global model study in GEOS-Chem, Atmos. Chem. Phys., 16, 11611186, https://doi.org/10.5194/acp-16-1161-2016, 2016a.

Sherwen, T., Schmidt, J. A., Evans, M. J., Carpenter, L. J., Großmann, K., Eastham, S. D., Jacob, D. J., Dix, B., Koenig, T. K., Sinreich, R., Ortega, I., Volkamer, R., Saiz-Lopez, A., PradosRoman, C., Mahajan, A. S., and Ordóñez, C.: Global impacts of tropospheric halogens $(\mathrm{Cl}, \mathrm{Br}, \mathrm{I})$ on oxidants and composi- 
tion in GEOS-Chem, Atmos. Chem. Phys., 16, 12239-12271, https://doi.org/10.5194/acp-16-12239-2016, 2016b.

Sherwen, T., Chance, R. J., Tinel, L., Ellis, D., Evans, M. J., and Carpenter, L. J.: A machine-learning-based global seasurface iodide distribution, Earth Syst. Sci. Data, 11, 1239-1262, https://doi.org/10.5194/essd-11-1239-2019, 2019.

Silva, S. J. and Heald, C. L.: Investigating Dry Deposition of Ozone to Vegetation, J. Geophys. Res.-Atmos., 123, 559-573, https://doi.org/10.1002/2017JD027278, 2018.

The International GEOS-Chem User Community: geoschem/geoschem: GEOS-Chem 12.1.1 (Version 12.1.1), Zenodo, https://doi.org/10.5281/zenodo.2249246, 13 December 2018.

Wang, Y., Jacob, D. J., and Logan, J. A.: Global simulation of tropospheric $\mathrm{O}_{3}-\mathrm{NO}_{x}$-hydrocarbon chemistry: 1. Model formulation, J. Geophys. Res.-Atmos., 103, 10713-10725, https://doi.org/10.1029/98JD00158, 1998.

Wesely, M.: Parameterization of surface resistances to gaseous dry deposition in regional-scale numerical models, Atmos. Environ., 23, 1293-1304, 1989.

Wesely, M. and Hicks, B.: Some Factors that Affect the Deposition Rates of Sulfur Dioxide and Similar Gases on Vegetation, JAPCA J. Air Waste Ma., 27, 1110-1116, https://doi.org/10.1080/00022470.1977.10470534, 1977.
Young, P., Naik, V., Fiore, A., Gaudel, A., Guo, J., Lin, M., Neu, J., Parrish, D., Rieder, H., Schnell, J., Tilmes, S., Wild, O., Zhang, L., Ziemke, J., Brandt, J., Delcloo, A., Doherty, R., Geels, C., Hegglin, M., Hu, L., Im, U., Kumar, R., Luhar, A., Murray, L., Plummer, D., Rodriguez, J., Saiz-Lopez, A., Schultz, M., Woodhouse, M., and Zeng, G.: Tropospheric Ozone Assessment Report: Assessment of global-scale model performance for global and regional ozone distributions, variability, and trends, Elem. Sci. Anth., 6, p. 10, https://doi.org/10.1525/elementa.265, 2018.

Young, P. J., Archibald, A. T., Bowman, K. W., Lamarque, J.-F., Naik, V., Stevenson, D. S., Tilmes, S., Voulgarakis, A., Wild, O., Bergmann, D., Cameron-Smith, P., Cionni, I., Collins, W. J., Dalsøren, S. B., Doherty, R. M., Eyring, V., Faluvegi, G., Horowitz, L. W., Josse, B., Lee, Y. H., MacKenzie, I. A., Nagashima, T., Plummer, D. A., Righi, M., Rumbold, S. T., Skeie, R. B., Shindell, D. T., Strode, S. A., Sudo, K., Szopa, S., and Zeng, G.: Preindustrial to end 21st century projections of tropospheric ozone from the Atmospheric Chemistry and Climate Model Intercomparison Project (ACCMIP), Atmos. Chem. Phys., 13, 20632090, https://doi.org/10.5194/acp-13-2063-2013, 2013.

Zweng, M., Reagan, J., Antonov, J., Locarnini, R., Mishonov, A., Boyer, T., Garcia, H., Baranova, O., Johnson, D., Seidov, D., and Biddle, M.: World Ocean Atlas 2013 Volume 2: Salinity, NOAA Atlas NESDIS, 74, 39, Silver Spring, Maryland, 2013. 